\title{
Jurisprudence Views on Producing Infant to Prove Rape
}

\author{
Bao Huang \\ Law School, Wuhan University \\ LuoJia Mountains, Wuhan 430072, China \\ Tel: 86-27-8349-9394Ｅ-mail: ku-boat@163.com
}

\begin{abstract}
PIPR is a painful way inferior group of social to rescue themselves. In China, police should take the proof burden in rape cases; production infant only testify sexual intercourse between victims and suspects, but not the acts of rape .This shows Chinese lack of evidence consciousness despite litigation increasing, police organs should take the initiative and the protection of human rights and further relief channels.
\end{abstract}

Keywords: PIPR, Rape cases, The burden of proof, Evidence awareness

\section{Introduction}

In the summer of 1999, Anhui province, a 15-year-old girl, who was raped produce infant to taking the criminals to jars; the summer of 2000, Guangdong province, a 15-year-old mentally handicapped girl, is pregnant after being raped, seeking fair treatment to let the innocent babies come to earth; in the autumn of 2000, Guangdong province, a 15-year-old girl was raped by her grandfather, produce infant to preserve evidence for trail; in the winter of 2000, Henan province, a 13-year-old girl, was repeatedly raped and pregnancy, in order to prosecute villain and produce infant; in the spring of 2003, Liaoning province, a 15-year-old mute girl was raped and pregnancy, in order to find the culprit and produce infant; in the autumn of 2005, Chongqing Municipalities, a 14-year-old girl is pregnant after being raped, producing infant in order to punish offenders; in the winter in 2005, Guizhou province, a 14-year-old girl is pregnant after being raped, producing infant in order to expose the lies of criminals; in the summer of 2006, Henan province, a 12-year-old girl produces infant in order to realize the justice in rape case.

The Producing Infant to Prove Rape (PIPR), is an alarming social phenomenon and a shocking methods of collecting evidence! What is PIPR? PIPR is a method to Prove Rape, in which victims produce infant. From a procedural perspective, PIPR means painful ways vulnerable groups of social take to save themselves; on the other hand, it reflects the procedural awareness of victims while lack of awareness of the evidence. Many victims in rape don't know how to protect themselves adequately and effectively. At the same time, PIPR showed that law enforcement agencies is poor in evidence, paying no attention to protecting the legitimate rights and interests of the weak, not providing remedy for the weak. Facing PIPR, everybody especially policeman and investigator should think over: what is problem with our criminal justice system? If the citizens become helpless in danger, what can he do?

\section{Punishment to Rape}

The case of rape is a serious offends to society and victims, which is stipulated in Criminal Code of every country and has a severe punishment.

According to Article 236 of Criminal code of P.R.C, Whoever rapes a woman by violence, coercion or any other means shall be sentenced to fixed-term imprisonment of not less than three years but not more than 10 years. Whoever has sexual intercourse with a girl under the age of 14 shall be deemed to have committed rape and shall be given a heavier punishment. Whoever rapes a woman or has sexual intercourse with a girl under the age of 14 shall, in any of the following circumstances, be sentenced to fixed-term imprisonment of not less than 10 years, life imprisonment or death:(1) the circumstances being flagrant;(2) raping a number of women or girls under the age of 14;(3) raping a woman before the public in a public place;(4) raping a woman with one or more persons in succession; or(5) causing serious injury or death to the victim or any other serious consequences.

The Sexual Offence Act 2003 of British, s.1 states: (1) A person (A) commits an offence if-(a) he intentionally penetrates the vagina, anus or mouth of another person (B) with his penis, (b)B does not consent to the penetration, and (c)A does not reasonably believe that B consents. From the Glenn Hutton's opinions, the issue of content is a question of fact and is critical to proving the offence of rape. It is also potentially the most difficult aspect of the offence to prove and that is why the legislation has included some specific sections raising presumptions and conclusions in certain circumstances. If the victim is a child under 13 , you simple have to prove intentional penetration and the child's age. No issue of "consent" arises and a specific offence under s.5 is committed. 


\section{Evidence views on PIPR}

Combination of the case mentioned above, I think a lot of evidence problem in the field of related issues we should explore and research.

\subsection{First evidence view: is it necessary to produce infant to prove rape?}

PIPR causes widespread concerning in the community, and an important reason for this is the way to achieve justice are unique, there was general understanding is: the price of realizing social justice is too high even though it may keep the criminals to take their responsibility (sometimes in fact,it also may not realize the goal).But the victim girls had to bear a heavy burden : their own mental stress and the due economical problem on the baby. Therefore, there is a problem worth considering: is it necessary to produce infant to prove rape? Is it the only way to produce infant to prove rape? Is it only to produce infant to prove the sexual intercourse between victim and criminal in cases of rape.

In fact, there are many channels to prove the sexual intercourse between victim and criminal in cases of rape, such as hair extract embryonic, amniotic fluid puncture or destroyed after the fetus to preserve an effective organization to identify its evidence and so on. Firstly, the method of extracting embryonic hair refers to the human embryo fertilized eggs after cleavage, and implantation of the blast cyst, by the second week of the weekend, that the first 14 days on the formation of a mesoderm and endoderm under the composition of the two oval-shaped plate mesoderm embryo, formation of human chorionic, At this point the body's other organs are not yet occurred. In other words, in the conception fetal hair after 14 days or so may have been formed through the hair of the embryo extraction and identification. Secondly, the method of amniotic fluid puncturing. Amniotic fluid in pregnancy refers to women with uterine amniotic fluid, which is the maintenance of fetal life by an important and indispensable component throughout the pregnancy. The amniotic fluid puncture is to have a pregnancy in the amniotic fluid through a simple apparatus, taking the number of $\mathrm{ml}$ under sterile and then have laboratory tests to determine the perpetrator of the technology. If analysising fetal chromosomes, it normally will take 2 weeks; and if determining AFP, a few days is Ok. Thirdly, the method of wipping out the fetus to preserve the organization. There is no significant difference between this method and PIPR, but the corresponding testing samples of this method is a dead body and PIPR is a living body.

\subsection{Second evidence view: is it possible to prove rape by producing infant?}

What is the purpose of PIPR? This question may be a bit ridiculous; the literal meaning of PIPR can be seen to testify the existence of rape. But according to Chinese law, crimes constitute four elements: the main body of crime, the object of the crime, crime subjective and crime objective. Among them, the main body of crime of rape is man who reached age of criminal responsibility (14 years old)and had capacity of criminal responsibility, the object of crime of rape is womens' sex rights, crime subjective of rape must be deliberately committed and direct deliberately, crime objective of rape is committed forcibly or violently or other means, or having sexual relations with young girls under 14 years of age. Because under 14 years of age, the girl is not yet mature physical or psychological, not knowing the nature of gender relations. Irrespective of using violence or not, people may constitute the crime of rape.

And the main body of crime and the main object of the crime are relatively easy to confirm, nor do they need to adopt PIPR. But the other two elements: subjective and objective aspects of crime are more complicated. How to tell deliberate from non-deliberate? How to identify the violence, coercion or other means to force sexual intercourse with them? It is very difficult to do so. Teenage victims of PIPR is actually a misunderstanding and still face the problem of proof burden. Whether the crime occurred is needing to confirm the sexual intercourse occurring firstly and to prove the sexual violation from women will. The act of producing infant can only prove the fact of whether sexual intercourse occurred or not ,and who is the baby's father.

But the act of producing infant can not prove that the latter issue - that is, the violation in the crime of rapecontrary to the will of women. Because the criminals may be argued, "I have a sexual relationship with the victim, but no to violence, coercion or other means." "Both of us are of mutual affection." The case referred in the beginning of this article in Guizhou province, PIPR can only prove the sexual relationship between the victim and Qiu ,but can not prove that it is contrary to the wishes of the victims. Fortunately, there has an agreement about the offend between the criminal and the victim, otherwise it is difficult to realize the society justice.

\subsection{Third evidence view: is it possible to prove rape by producing infant?}

According to the relevant provisions of Chinese Criminal Procedure code, criminal cases in China can be divided into two kinds: private prosecution and public prosecution. The main choice is public prosecution, supplementing by private prosecution. In fact, From the historical development process, the prosecution system had been private prosecution .In ancient times, victims took vengeance on the offender directly. With the development of criminal prosecution system, the scope of the complainant by victims extend to the general public, the general public can also exercise the right to complaints. Along with social development, in-depth understanding of the nature of the crime, single private prosecution have been unable to meet the needs of criminal punishment. In 14th century, on behalf of the state, crime prosecution and procurator organs of the Prosecutor were set up in France. Indictment from countries has gradually 
become the main criminal prosecution system in the world.

The rape is a typical case of public prosecution. In rape case, victims don't need to give evidence to state organs. In studying the burden of proof, we have too much concern who should be taken the responsibility between police organs and criminal suspects, but few address Who should bear the responsibility between police organs and victims. From the indictment history, the burden of proof was beyond victim's ability, so police organs should take the burden of proof in rape cases.

From article 84 of Chinese Criminal Procedure code, any unit or individual, upon discovering facts of a crime or a criminal suspect, shall have the right and duty to report the case or provide information to a public security organ, a People's Procuratorate or a People's Court. When his personal or property rights are infringed upon, the victim shall have the right to report to a public security organ, a People's Procuratorate or a People's Court about the facts of the crime or bring a complaint to it against the criminal suspect. so in the case of rape, the only thing victims should do is to report or provide information to, and she only need identify themselves by an aggression upon women's rights, regardless of who commit the crime or how many evidence of crime is. Jurisdiction of Rape acts belongs to the police organs, which should seize the suspect and collect evidence.

\section{Jurisprudence thinking about PIPR}

As an act contrary to the wishes of the women, rape is a serial crime that the criminals are forcing the victim to have sex by using violence, threats or injury and other means. In almost all countries, rape is a serial crime, so does our criminal law. The criminals of rape violate victims the inviolability of the sex rights of women, who has the right to refuse to accept anybody except their spouses. The victim in PIPR has been gotten double harm - by the criminals and the social system, legal system and even a specific law enforcement agencies which should protect the rights of victims to ignore the damage. From the existence of PIPR, we should learn something.

\subsection{Person has more legal awareness while evidence consciousness remains weak}

PIPR shows that the people's legal awareness has been greatly enhanced in violation of the rights and interests of their own time. (Even if some "detrimental to the reputation" of events such as rape, insult etc which original was ashamed for others to understand.) From various channels, people have the courage to pursue crime, punishment of crimes, knowing how to protect their rights and interests. This is a great progress! This is the action of our national sense of progress, but also the sense of social civilization and progress.

At the same time, victims are lack of the sense of collecting evidence. If the female victims could retain the corresponding evidence of rape in the spot, it is unnecessary to producing infant to prove rape. Just as the formal president Clinton`s sexual scandal of United States, victim Lewinsky keeps the skirts so long and can be used as evidence later in court. Many victims in PIPR simply do not have this sense, after being raped, the first thing should be rushed away the evidence (including vaginal secretions and clothing). Some victim in PIPR are being raped many times, but no one can retain any related evidence, such as semen underwear, sanitary napkins or, underwear, towels, bed sheets, towels or condoms, and so on. If doing so, with chelex-100 method of DNA extraction, police can make confident on offender.

\subsection{The protection of human rights and the sense of evidence collection should be strengthened}

Investigation department should pay more attention to insist on the protection of human rights. Compared to the other departments in the proceedings, the human rights of criminal suspects is in need of special concerning, which is the main themes of China's research field of protection of human rights in recent years one. However, this does not mean that the investigation attention should be focused only limited to the human rights of criminal suspects, other Participants in lawsuit should also be involved in, especially victim's human rights. A long time ago, victims in criminal proceedings is often seen as nothing to do with the role of their status and rights is very limited or no's. In essence, justice should not be biased in favor of any party, the plaintiff (victim) and the accused (suspects) should not be too cold or favor, the parties should maintain balance in the proceedings. To end this situation, 1996`s amendment of Criminal Procedure Code regards the victims as the Criminal parties`status. British report on judicial reform in 2002-Justice for All, also made clear to establish the victims as the core of the achievement of just system of criminal justice, it says that victims and witnesses should give better Treatment. From the historical origins 'view, the functions of investigation determine investigators should use the power to detect the emergence and growth of individual victims.

In addition, there are some saying that the fee of DNA identification is more than 3,000RMB Yuan, it is difficulty for the victims, who think producing birth to Infant much cheaper. This is a misunderstanding for China's legal system. According to article 2 of the cost of litigation payment by the State Council. the parties of civil and administrative proceedings should pay for litigation. Article 76 of hearing criminal proceedings on the specific provisions by the Supreme People's Court provides that the indictment filed in the case of civil suit collateral and the people's courts do not charge legal fees. Therefore, whether criminal or civil proceedings are not required to pay an annual fringe litigation costs. Applicants commitment in criminal cases are still basically the same, forensic identification are generally 
conducted without charging any fees, appraisal fees and allow victims to bear no legal basis. Of course, it is undeniable that the cost involved in handling cases of identification, due to various factors, by the State in the annual financial resources often is only a small part and the majority of which rely on the unit to resolve. Sometimes, police organs are unable to identify the needed commissioned and should ask help from the social intermediary organizations or other bodies, which spend a lot of money and even affect the quality and efficiency of handling cases. Therefore, in judicial practice, some police organs ask victims to pay their identification costs (particularly those entrusted identification), but this is illegal.

\subsection{Situation of lacking of social relief and judicial remedy should be changed}

From a sociological point of view, as a social phenomenon existence in our society, PIPR maybe should be avoided in the beginning. 14-15 years old girl, as children themselves, should have been in the care of the parents and lead a carefree life. However, they were violated illegal, family and school can not build a safety network to protect the rights and interests of minors. The justice departments can not seek justice for them quickly and decisively, helping them out of the shadow of rape, Instead of pushing them to PIPR this bitter road. The results of PIPR are only tri-loser and no winner. The victim is a double harm by unlawful sexual abuse on the one hand, it has been battered physically and mentally; on the other hand it has prematurely into the ranks of the mother, making them the future of the heavy shadow of life. On the education of children born out of wedlock, it is also a kind of unfair. In the next life, children born out of wedlock will suffer discrimination of single-parent families and the father is a rapist. For the community and the state, PIPR shows our society and the state's system a bitter irony: our mechanism for the protection of the rights and interests of minors are too weak to protect them. If there are any schools to teach them some sense of self-defense, if the families can found children's physical and mental changing, if the community can provide several channels of rights, if China Women's Federation and other departments can protect the weak on time for intervention and help for victims, if justice is not so powerless ......., then is PIPR tragedy continue?

In fact, while investigation department has an excuse of "there can not collect evidence from a long time ago, our judicial remedy and relief channels did not end. According to our law, the victim may ask the People's Procuratorate for the exercise of the right to supervise or sue to the people Court as a private prosecution directly. Article 87 of Criminal Procedure Code states: Where a People's Procuratorate considers that a case should be filed for investigation by a public security organ but the latter has not done so, or where a victim considers that a case should be filed for investigation by a public security organ but the latter has not done so and the victim has brought the matter to a People s Procuratorate, the People's Procuratorate shall request the public security organ to state the reasons for not filing the case. If the People's Procuratorate considers that the reasons for not filing the case given by the public security organ are untenable, it shall notify the public security organ to file the case, and upon receiving the notification, the public security organ shall file the case. In addition, if there is evidence that proves the accused violate the victims' persons, property rights and the accused should be held criminal responsibility, but the People's Procuratorate, public security organs do not to prosecute the criminal responsibility of the accused, the victims could sue to the People's Court directly as a private prosecution (Article 170 of Criminal Procedure Code). It is known as the "Public Prosecution to Private Prosecution" in our criminal procedure law.

\section{References}

Z. Adler. (1987). Rape on Trial, Routledge Books Ltd.

Jennifer Temkin. (2002). Rape and the Legal Process (Oxford Monographs on Criminal Law \& Justice), Oxford University Press.

Ian Pepper. (2004). Crime Scene Investigation: Methods and Procedures, Open University Press.

Peter Murphy. (2004). Blackstone`s Criminal Practice. Oxford University Press.

Susan Easton. (2005). Christine Piper, Sentencing and Punishment: The Quest for Justice, Oxford University Press.

Mike Nash. (2006). Public Protection and the Criminal Justice Process, Oxford University Press.

Fraser Sampson. (2007). Blackstone `s Police Manual Volume l Crime. Oxford University Press.

Glenn Hutton, David Johnston \& Fraser Sampson. (2006). Blackstone`s Police Investigator's Manual. Oxford University Press.

Tim Newburn. (2007). Handbook of Criminal Investigation, Willan Publishing.

Michael Newton. (2008). The Encyclopedia of Crime Scene Investigation, Checkmark Books.

James Bennett. (2008). Crime Investigation: The Ultimate Guide to Forensic Science, Parragon Books Ltd.

S Caringella. (2008). Addressing Rape Reform in Law and Practice, Columbia University Press. 